\title{
Interaction of erythromycin and clarithromycin with orange juice
}

\author{
Arini Setiawati, Metta Sinta Sari Wiria, Franciscus D. Suyatna, Juan Tjiu Sion, Marina Hamadian
}

\begin{abstract}
Abstrak
Pemberian jus jeruk dengan feksofenadin telah ditemukan menurunkan bioavailabilitas feksofenadin sampai kurang dari $30 \%$ melalui hambatan organic-anion transporting polypeptide (OATP), suatu polipeptida yang mentransport obat ke dalam sel dan terdapat pada organ-organ seperti hati, ginjal dan usus. Eritromisin dan klaritromisin adalah substrat dan penghambat CYP3A4, suatu enzim pemetabolisme obat di hati dan usus, dan P-glikoprotein (P-gp), protein yang mentransport obat ke luar dari sel. Karena terdapat tumpang tindih antara substrat dan penghambat CYP3A4, P-gp dan OATP, kami ingin meneliti apakah pemberian bersama jus jeruk lokal (jeruk Siam) akan mempengaruhi bioavailabilitas ke-2 antibakteri tersebut di atas. Kami melakukan 2 studi menyilang, satu studi untuk setiap antibakteri $(500 \mathrm{mg})$, yang diberikan bersama jus jeruk (200 ml) dan bersama air pada 12-13 sukarelawan sehat per studi. Kadar serum antibakteri diukur dengan cara mikrobiologik. Rasio rata-rata (kisaran) AUC 0 - dengan jus jeruk / dengan air adalah sbb.: eritromisin : total $(n=13) 81.7(9.7-193.8) \%$, tidak berubah $(n=4) 96.4(80.5-107.9) \%$, menurun $(n=6) 31.9$ (9.7-49.0)\%, meningkat $(n=3) 161.8$ (134.6-193.8)\%; klaritromisin : total $(n=12) 91.4(20.6-158.3) \%$, tidak berubah $(n=5) 103.1(80.9-123.0) \%$, menurun (n=4) 34.8 (20.6-64.3)\%, meningkat (n=3) 147.2 (132.9-158.3)\%. Disimpulkan bahwa pemberian eritromisin atau klaritromisin bersama jus jeruk Siam menghasilkan efek yang tidak konsisten terhadap bioavailabilitas ke-2 antibakteri ini pada masing-masing subyek, dengan penurunan yang besar pada hampir separuh dari subyek, meskipun secara total efeknya tidak bermakna secara statistik. (Med J Indones 2005; 14: 78-86)
\end{abstract}

\begin{abstract}
Concomitant administration of orange juice with fexofenadine has been found to decrease the bioavailability of fenofenadine to less than $30 \%$ via inhibition of organic-anion transporting polypeptide (OATP), a drug uptake transporter expressed in organs such as liver, kidney and intestine. Erythromycin and clarithromycin are substrates and inhibitors of CYP3A4, a drug metabolizing enzyme in the liver and enterocytes, and P-glycoprotein (P-gp), a drug efflux transporter expressed in the same organs as OATP. Since an extensive overlap exists between substrates and inhibitors of CYP3A4, P-gp and OATP transporters, we want to study the effect of coadministration of our local orange (Siam orange) juice on the bioavailability of the above antibacterials. We conducted two 2 -way cross-over randomized studies, one study for each antibacterial (500 $\mathrm{mg}$ ), crossed between administration with orange juice (200 ml) and with water, in 12-13 healthy subjects per study. The serum concentrations of the antibacterials were assayed by microbiological method. The mean (range) ratio of $A U C_{0-t}$ with orange juice/with water were as follows : erythromycin : total (n=13) 81.7 (9.7-193.8)\%, unchanged $(n=4) 96.4(80.5-107.9) \%$, decreased $(n=6) 31.9(9.7-49.0) \%$, increased $(n=3) 161.8(134.6-193.8) \%$; clarithromycin : total $(n=12) 91.4(20.6-158.3) \%$, unchanged $(n=5) 103.1(80.9-123.0) \%$, decreased $(n=4) 34.8(20.6-64.3) \%$, increased $(n=3) 147.2$ (132.9-158.3)\%. It was concluded that coadministration of Siam orange juice with erythromycin or clarithromycin produced unpredictable effects on the bioavailability of these antibacterials in individual subjects, with marked decreases in almost half of the subjects, although in totals the effects were not statistically significant. (Med J Indones 2005; 14: 78-86)
\end{abstract}

Keywords: interaction, erythromycin, clarithromycin, orange juice.

Concomitant administration of orange juice with fexofenadine has been found to decrease the bioavailability of fexofenadine to less than $30 \%$ via inhibition of organic-anion transporting polypeptide (OATP). ${ }^{1}$ Fexofenadine is a nonsedating antihistamine

Department of Pharmacology and Therapeutics, Faculty of Medicine, University of Indonesia, Jakarta, Indonesia with negligible metabolism in humans and has been identified as a substrate of OATP and P-glycoprotein $(\mathrm{P}-\mathrm{gp}) .^{2}$ While OATP is a drug uptake transporter, P-gp is a drug efflux transporter, and both transporters colocalize in tissues for drug absorption and disposition such as the intestinal mucosa, renal proximal tubules, liver cells and blood-brain barrier. ${ }^{3}$

Erythromycin and clarithromycin are known to be substrates and inhibitors of CYP3A4. ${ }^{4}$ CYP3A4 is the 
most important isoenzyme of cytochrome P450 metabolizing enzymes because it metabolizes the widest range of drugs and endogenous compounds in humans, and it is the most abundant cytochrome enzymes in the liver and in enterocytes. ${ }^{4}$ Erythromycin and clarithromycin are also known as substrates and inhibitors of P-gp. ${ }^{5-7}$ Erythromycin is also an inhibitor of OATP. ${ }^{3}$

Since antibacterials are commonly administered with fruit juices, we want to study the effect of coadministration of our local orange (Siam orange) juice on the bioavailability of the above antibacterials.

\section{METHODS}

\section{Materials}

Erythromycin $500 \mathrm{mg}$ tablets and clarithromycin 500 $\mathrm{mg}$ tablets were obtained from Abbott Indonesia $\left(\right.$ Erythrocin $^{\circledR}$ and Abbotic ${ }^{\circledR}$ ).

Orange juice was prepared by squeezing our local orange (Siam orange), 5 to 6 fruits produced $200 \mathrm{ml}$ of the juice.

\section{Subjects}

Male and female healthy volunteers, aged between 18 to 55 years with normal body weight. Healthy was assessed based on medical history, physical examination, and clinical laboratory tests (routine hematology, renal and liver function tests, blood glucose and urinalysis). Subjects with known contraindication or hypersensitivity to the antibacterials being studied and to orange juice, and also subjects with gastritis or peptic ulcer were excluded from the study. No drugs (including vitamins and herbal medicines) were allowed one week before and during the study period.

\section{Study design and procedure}

Two 2-way cross-over randomized studies were conducted, one study for each antibacterial. Each study included 12-13 volunteers. The study protocols were approved by the Ethics Committee of our institution and each study was conducted in compliance with the Good Clinical Practice standards. Written informed consent was obtained from each subject prior to the study.
Subjects should refrain from smoking or drinking alcohol, coffee, tea, cola or chocolate for 24 hours before and during the sampling day. After 12 hours fasting, a single antibacterial tablet was administered with either $200 \mathrm{ml}$ of Siam orange juice or $200 \mathrm{ml}$ of water. Breakfast was given 2.5 hours later. Food and drink consumed by the subjects, and their physical activity, were standardized during the sampling day. After a wash-out period of 2 weeks, the procedure was repeated with the same antibacterial administered with the alternate drink.

Venous blood samples $(3 \mathrm{ml})$ were drawn before drug administration (at 0 hour) and at several time points afterwards. For erythromycin, the time points were : 0 and $0.5,1,1.5,2,3,4,5,7$ and 9 hours post dose. For clarithromycin : 0, 0.5, 1, 1.5, 2, 3, 4, 6, 9 and 12 hours. The serums were separated and kept in the freezer before antibacterial assay on the subsequent days.

\section{Antibacterial assay}

The antibacterial concentrations in serums were assayed by microbiological method. The microorganisms used for the assay were Sarcina lutea ATCC 49732 for both erythromycin and clarithromycin.

The limit of quantitation (LoQ), accuracy (recovery) and precision (coefficient of variation $=\mathrm{CV}$ ) of the assay for erythromycin were $0.05 \mu \mathrm{g} / \mathrm{ml}, 91-106 \%$ and 5-26\%, respectively; and for clarithromycin were $0.10 \mu \mathrm{g} / \mathrm{ml}, 90-112 \%$ and $17-23 \%$, respectively.

\section{Pharmacokinetic parameters}

The peak serum concentration $\left(\mathrm{C}_{\max }\right)$ and the time to peak serum concentration $\left(\mathrm{t}_{\mathrm{max}}\right)$ were obtained directly from the observed values. The area under the serum concentration versus time curve from time 0 to the last sampling time $\left(\mathrm{AUC}_{0-\mathrm{t}}\right)$ was calculated using the trapezoidal method. The elimination half-life $\left(t^{1} / 2\right)$ was calculated as $0.693 / \mathrm{k}_{\mathrm{e}}$. The terminal elimination rate constant $\left(\mathrm{k}_{\mathrm{e}}\right)$ was the slope of the linear regression calculated from 3 to $4 \log$ concentrations at the terminal phase of the concentration-time curve.

The bioavailability parameters are AUC, $\mathrm{C}_{\max }$, and $\mathrm{t}_{\max }$; and AUC is considered the most important parameter.

\section{Data analysis}

To compare the bioavailability parameters of each antibacterial administered with Siam orange juice and 
with plain water, paired-t test was used on logtransformed values of $\mathrm{AUC}$ and $\mathrm{C}_{\max }$, while Wilcoxon matched-pairs test on untransformed values of $t_{\max }$ and $t^{1 / 2}$. The level of significance $\alpha$ was set at 0.05 .

The effect of orange juice on the bioavailability of each antibacterial was assessed in each subject by calculating the ratio of the AUC with orange juice to that with water. The bioavailability was considered as unchanged when the AUC ratio ranged from 0.80 to 1.25. AUC ratio of less than 0.80 or more than 1.25 was considered as decreased or increased, respectively. These criteria were adopted from standard bioequivalence guidelines, in which the range of bioequivalence was set at 0.80 1.25 for AUC ratio.

\section{RESULTS}

\section{Erythromycin}

Figure 1 shows the serum concentration-time curves of erythromycin after administration of erythromycin 500 $\mathrm{mg}$ tablet with water and with orange juice in 13 subjects. The mean serum concentrations with orange juice were lower at each sampling time than those with water.

The bioavailability parameters of erythromycin administered with water and with orange juice are presented in Table 1. The $\mathrm{AUC}_{0-9 h r}$ with orange juice was lower than that with water, but the difference did not reach statistical significance. The $C_{\max }$ with orange juice was also lower than that with water, but the difference was also not statistically significant.

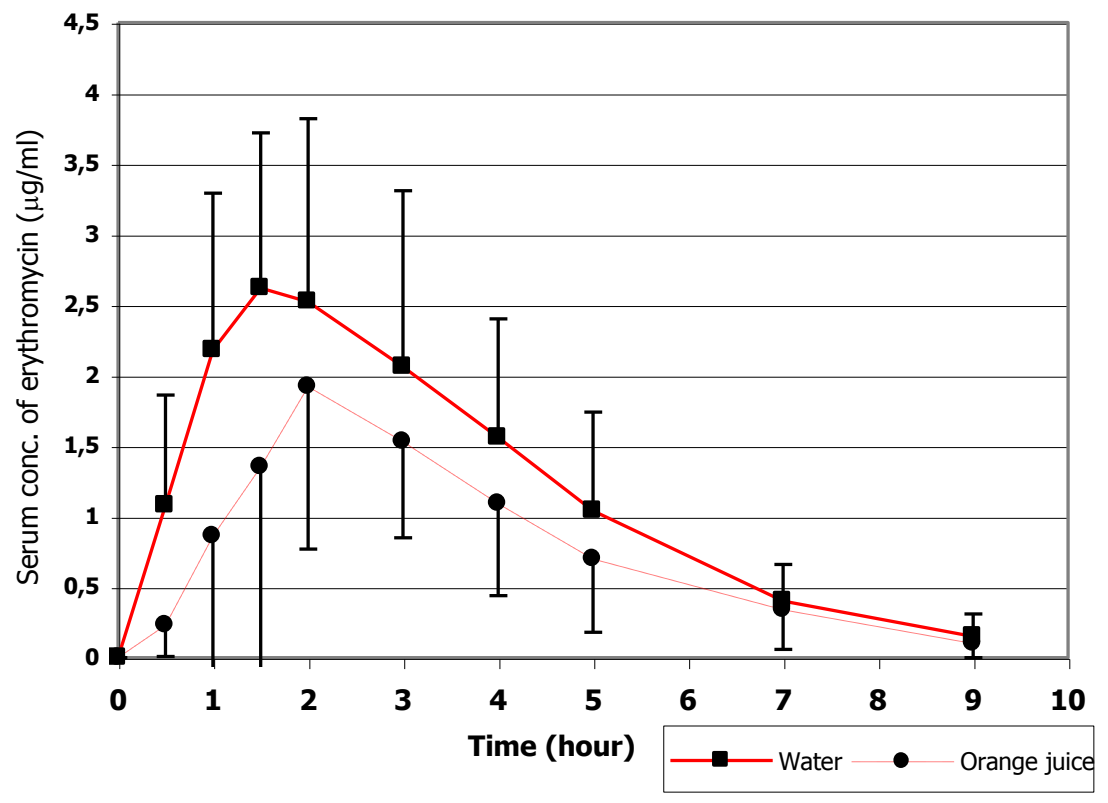

Figure 1. Mean (SD) serum concentrations of erythromycin in 13 subjects after oral administration of $500 \mathrm{mg}$ Erythrocin ${ }^{\circledR}$ tablet with water and with orange juice

Table 1. Bioavailability parameters of erythromycin administered with water and with Siam orange juice

\begin{tabular}{lcccccccc}
\hline & \multicolumn{2}{c}{$\mathrm{AUC}_{0-9 h r}(\mu \mathrm{g} / \mathrm{ml} . \mathrm{hr})$} & \multicolumn{2}{c}{$\mathrm{C}_{\max }(\mu \mathrm{g} / \mathrm{ml})$} & \multicolumn{2}{c}{$\mathrm{t}_{\max }(\mathrm{hr})$} & \multicolumn{2}{c}{$\mathrm{t} / 2(\mathrm{hr})$} \\
\cline { 2 - 9 } & Water & Orange juice & Water & Orange juice & Water & Orange juice & Water & Orange juice \\
\hline Mean & 10.94 & 7.11 & 3.06 & 2.45 & 1.69 & 2.04 & 1.73 & 1.63 \\
Range & $1.96-18.33$ & $1.78-15.59$ & $0.90-4.87$ & $0.73-5.09$ & $1-3$ & $1-3$ & $1.14-2.55$ & $0.87-2.24$ \\
$\mathrm{p}$ & \multicolumn{2}{c}{0.065 (NS) } & \multicolumn{2}{c}{0.173 (NS) } & \multicolumn{2}{c}{0.156 (NS) } & \multicolumn{2}{c}{0.249 (NS) } \\
\hline
\end{tabular}


The effect of Siam orange juice on the bioavailability $\left(\mathrm{AUC}_{0-9 h \mathrm{hr}}\right)$ of erythromycin are shown in Table 2. Among 13 subjects, orange juice decreased erythromycin bioavailability in 6 subjects, did not change that in 4 subjects and increased that in 3 subjects. The individual AUC ratio is shown clearly in Figure 2.

Table 2. The effect of Siam orange juice on the bioavailability $\left(\mathrm{AUC}_{0-9 \mathrm{hr}}\right)$ of erythromycin in each subject

\begin{tabular}{|c|c|c|c|c|}
\hline \multirow{2}{*}{$\begin{array}{l}\text { Erythromycin } \\
\text { bioavailability }\end{array}$} & \multirow{2}{*}{\multicolumn{2}{|c|}{$\begin{array}{l}\text { Ratio of } \mathrm{AUC}_{0-9 \mathrm{hr}} \\
\text { with orange juice / with water }\end{array}$}} & \multicolumn{2}{|c|}{$\mathrm{AUC}_{0-9 \mathrm{hr}}$} \\
\hline & & & Water & Orange juice \\
\hline \multirow{6}{*}{$\begin{array}{l}\text { Decreased } \\
\quad(n=6)\end{array}$} & $<0.80$ & 0.097 & 18.33 & 1.78 \\
\hline & & 0.249 & 13.98 & 3.48 \\
\hline & & 0.335 & 7.49 & 2.51 \\
\hline & & 0.339 & 14.51 & 4.92 \\
\hline & & 0.403 & 10.98 & 4.42 \\
\hline & & 0.490 & 15.79 & 7.73 \\
\hline Mean & & 0.319 & 13.51 & 4.14 \\
\hline Range & & $0.097-0.490$ & $7.49-18.33$ & $1.78-7.73$ \\
\hline \multirow{4}{*}{$\begin{array}{l}\text { Unchanged } \\
\quad(\mathrm{n}=4)\end{array}$} & $0.80-1.25$ & 0.805 & 13.22 & 10.64 \\
\hline & & 0.932 & 16.72 & 15.59 \\
\hline & & 1.039 & 5.70 & 5.92 \\
\hline & & 1.079 & 8.97 & 9.68 \\
\hline Mean & & 0.964 & 11.15 & 10.46 \\
\hline Range & & $0.805-1.079$ & $5.70-16.72$ & $5.92-15.59$ \\
\hline \multirow{3}{*}{$\begin{array}{l}\text { Increased } \\
\quad(n=3)\end{array}$} & $>1.25$ & 1.346 & 9.44 & 12.71 \\
\hline & & 1.571 & 1.96 & 3.08 \\
\hline & & 1.938 & 5.16 & 10.00 \\
\hline Mean & & 1.619 & 5.52 & 8.60 \\
\hline Range & & $1.346-1.938$ & $1.96-9.44$ & $3.08-12.71$ \\
\hline \multicolumn{5}{|l|}{ Total $(n=13)$} \\
\hline Mean & & 0.817 & 10.94 & 7.11 \\
\hline Range & & $0.097-1.938$ & $1.96-18.33$ & $1.78-15.59$ \\
\hline
\end{tabular}

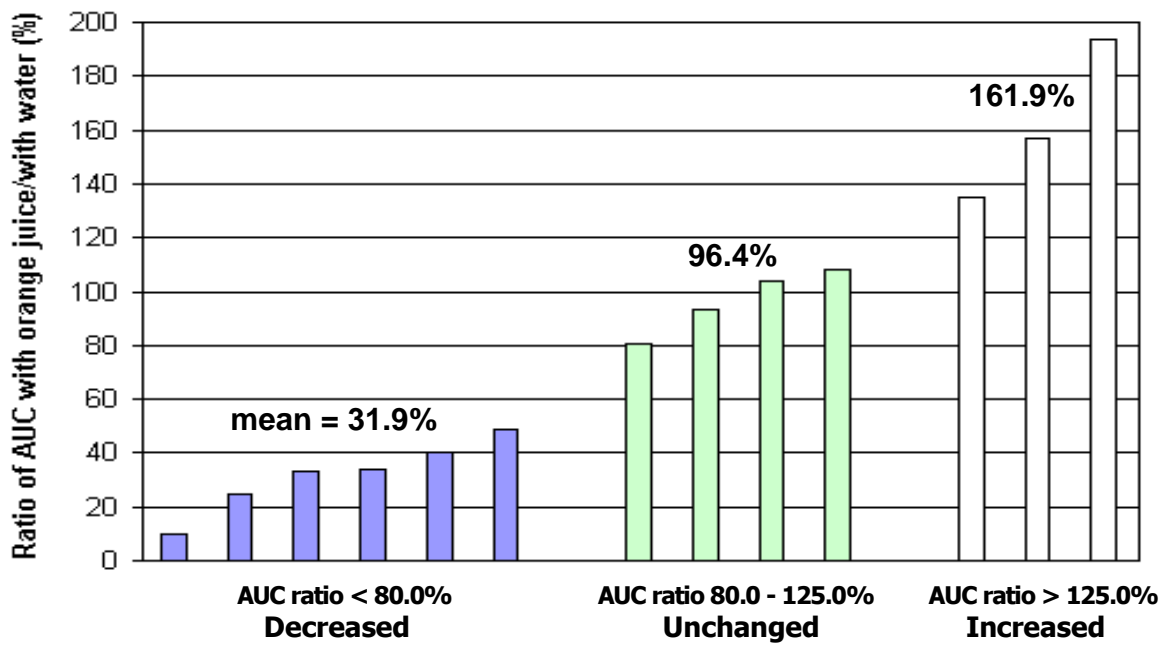

Figure 2. The effect of Siam orange juice on the bioavailability $\left(A U C_{0-9 h r}\right)$ of erythromycin in each subject 


\section{Clarithromycin}

The clarithromycin study included 13 subjects. However, in one subject, the bioavailability with orange juice increased more than 5 times the bioavailability with water. This was considered impossible because the absolute oral bioavailability of clarithromyvcin is around $55 \%,{ }^{8}$ so that the maximum increase will be not more than twice. Therefore data from this subject was excluded from the analysis, leaving 12 subjects to be analyzed.

The serum concentration-time curves of clarithromycin in 12 subjects after administration of clarithromycin $500 \mathrm{mg}$ tablet with water and with orange juice is shown in Figure 3. The mean serum concentrations of clarithromycin with orange juice were similar at 1, 1.5, and 2 hours after administration than those with water, but slightly lower at the other time points.

The bioavailability parameters of clarithromycin administered with water and with orange juice are listed in Table 3. The $\mathrm{AUC}_{0-12 \mathrm{hr}}$ with orange juice was lower than that with water, but the difference was not statistically significant. The $\mathrm{C}_{\max }$ with orange juice was slightly higher than that with water, but the difference was also not statistically significant.

The effect of Siam orange juice on the bioavailability $\left(\mathrm{AUC}_{0-12 \mathrm{hr}}\right)$ of clarithromycin are presented in Table 4. Among 12 subjects, orange juice decreased clarithromycin bioavailability in 4 subjects, did not change that in 5 subjects and increased that in 3 subjects. The individual AUC ratio is shown clearly in Figure 4.

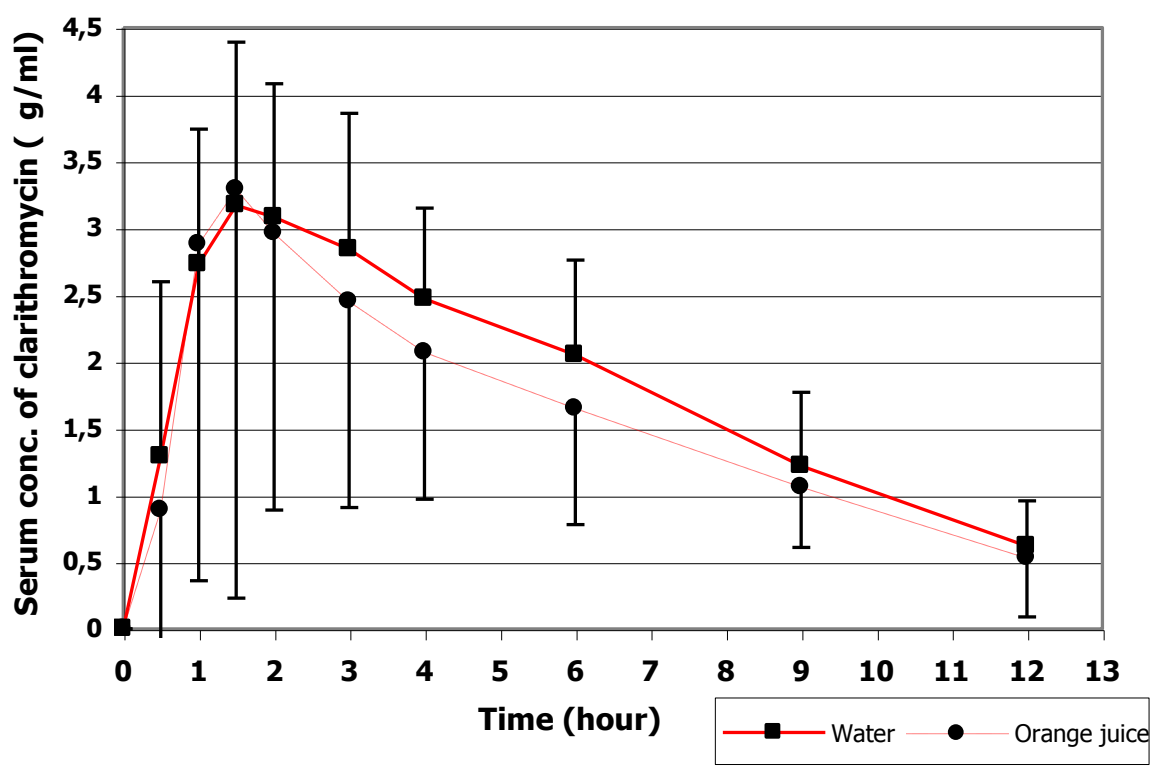

Figure 3. Mean (SD) serum concentrations of clarithromycin in 12 subjects after oral administration of $500 \mathrm{mg}$ Abbotic ${ }^{\circledR}$ tablet with water and with orange juice

Table 3. Bioavailability parameters of clarithromycin administered with water and with Siam orange juice

\begin{tabular}{|c|c|c|c|c|c|c|c|c|}
\hline & \multicolumn{2}{|c|}{$\mathrm{AUC}_{0-12 \mathrm{hr}}(\mu \mathrm{g} / \mathrm{ml} . \mathrm{hr})$} & \multicolumn{2}{|c|}{$\mathrm{C}_{\max }(\mu \mathrm{g} / \mathrm{ml})$} & \multicolumn{2}{|c|}{$\mathrm{t}_{\max }(\mathrm{hr})$} & \multicolumn{2}{|c|}{$\mathrm{t} t / 2(\mathrm{hr})$} \\
\hline & Water & Orange juice & Water & Orange juice & Water & Orange juice & Water & Orange juice \\
\hline Mean & 17.92 & 15.45 & 3.58 & 3.85 & 2.08 & 2.08 & 4.45 & 5.44 \\
\hline Range & $5.13-29.48$ & $3.84-31.76$ & $1.10-5.21$ & $0.65-10.42$ & 0.54 & $1-6$ & $2.82-7.22$ & $2.22-18.81$ \\
\hline $\mathrm{p}$ & \multicolumn{2}{|c|}{$0.204(\mathrm{NS})$} & \multicolumn{2}{|c|}{0.540 (NS) } & \multicolumn{2}{|c|}{$0.530(\mathrm{NS})$} & \multicolumn{2}{|c|}{0.779 (NS) } \\
\hline
\end{tabular}


Table 4. The effect of Siam orange juice on the bioavailability $\left(\mathrm{AUC}_{0-12 \mathrm{hr}}\right)$ of clarithromycin in each subject

\begin{tabular}{|c|c|c|c|c|}
\hline \multirow{2}{*}{$\begin{array}{l}\text { Erythromycin } \\
\text { bioavailability }\end{array}$} & \multirow{2}{*}{\multicolumn{2}{|c|}{$\begin{array}{l}\text { Ratio of } \mathrm{AUC}_{0-12 \mathrm{hr}} \\
\text { with orange juice / with water }\end{array}$}} & \multicolumn{2}{|c|}{$\mathrm{AUC}_{0-12 \mathrm{hr}}$} \\
\hline & & & Water & Orange juice \\
\hline \multirow{4}{*}{$\begin{array}{l}\text { Decreased } \\
\quad(n=4)\end{array}$} & $<0.80$ & 0.206 & 29.48 & 6.08 \\
\hline & & 0.240 & 15.99 & 3.84 \\
\hline & & 0.304 & 15.44 & 4.70 \\
\hline & & 0.643 & 17.20 & 11.07 \\
\hline Mean & & 0.348 & 19.53 & 6.42 \\
\hline Range & & $0.206-0.643$ & $15.44-29.48$ & $3.84-11.07$ \\
\hline \multirow{5}{*}{$\begin{array}{l}\text { Unchanged } \\
(\mathrm{n}=5)\end{array}$} & $0.80-1.25$ & 0.809 & 15.41 & 12.47 \\
\hline & & 0.964 & 19.11 & 18.43 \\
\hline & & 0.999 & 22.57 & 22.55 \\
\hline & & 1.155 & 18.51 & 21.38 \\
\hline & & 1.230 & 12.98 & 15.96 \\
\hline Mean & & 1.031 & 17.72 & 18.16 \\
\hline Range & & $0.809-1.230$ & $12.98-22.57$ & $12.47-22.55$ \\
\hline \multirow{3}{*}{$\begin{array}{l}\text { Increased } \\
\quad(n=3)\end{array}$} & $>1.25$ & 1.329 & 23.90 & 31.76 \\
\hline & & 1.505 & 19.26 & 28.99 \\
\hline & & 1.583 & 5.13 & 8.12 \\
\hline Mean & & 1.472 & 16.10 & 22.96 \\
\hline Range & & $1.329-1.583$ & $5.13-23.90$ & $8.12-31.76$ \\
\hline \multicolumn{5}{|l|}{ Total $(n=12)$} \\
\hline Mean & & 0.914 & 17.92 & 15.45 \\
\hline Range & & $0.206-1.583$ & $5.13-29.48$ & $3.84-31.76$ \\
\hline
\end{tabular}

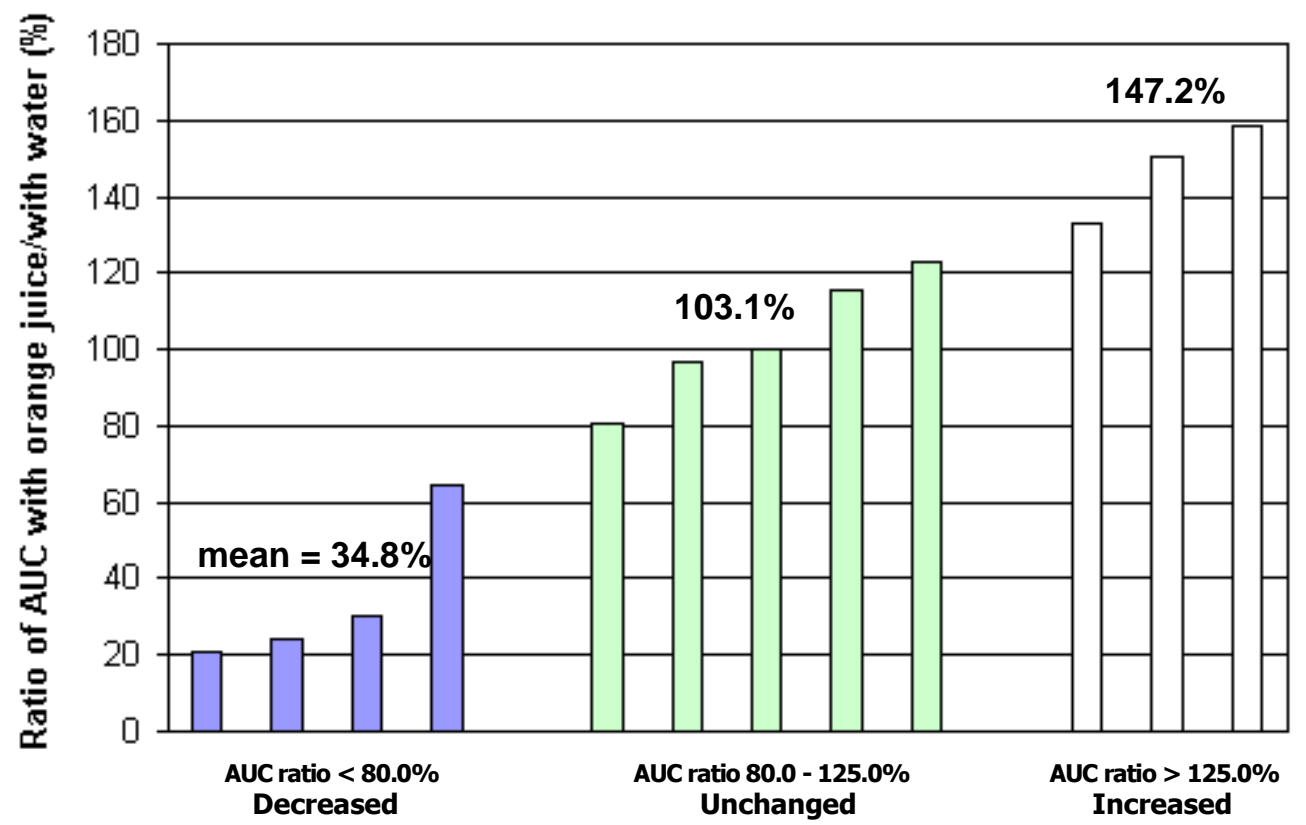

Figure 4. The effect of Siam orange juice on the bioavailability $\left(A U C_{0-12 h r}\right)$ of clarithromycin in each subject 


\section{DISCUSSION}

CYP3A, P-gp and OATP are present in enterocytes and hepatocytes, and therefore responsible for modulation of oral bioavailability and hepatic clearance. A substantial overlap exists in the substrates, inhibitors and inducers of human CYP3A, P-gp and OATP. ${ }^{2,7,9,10}$ CYP3A and P-gp act synergistically to decrease the bioavailability of drugs which are substrates of both systems (first-pass elimination), while OATP produces the reverse effect. The result will depend on the dominant system, and it varies among individuals. The same inhibitor or inducer may affect those 3 systems, with again variable results depending on the dominant system.

Siam orange (Citrus nobilis Lour var microcarpa) is our local orange, the mostly consumed orange in Indonesia, approximately $60 \%$ of oranges in the market. Siam orange has been known to contain some flavonoids, i.e. hesperidin, didimin, eriositrin and narirutin. ${ }^{11,12}$ Hesperidin is one of the bioflavonoids which has been shown by Dresser et $\mathrm{al}^{1}$ to be an inhibitor of rat Oatp3 activity.

Siam orange juice does not contain dihydroxybergamottin nor flavonoids naringin and naringenin ${ }^{13}$ which inhibit intestinal CYP3A4. Dresser et al. ${ }^{14}$ have shown in an in vitro study that citrus juices (grapefruit juice and orange juice) were potent inhibitors of intestinal OATP but only modest inhibitors of intestinal P-gp.

The bioavailability of erythromycin is determined by its absorption across intestinal epithelial cells by passive diffusion, its metabolism by CYP3A4 in the enterocytes and hepatocytes, ${ }^{4}$ its efflux by P-gp from the enterocytes back to the intestinal lumen,, 7 and its uptake by OATP from the intestinal lumen into the enterocytes (not yet known). Passive diffusion is a passive process and therefore not affected by other compounds (no interaction). Erythromycin is a substrate of both CYP3A44 and P-gp, ${ }^{4,7}$ which cooperate to result in decreased bioavailability of erythromycin. Inhibition of CYP3A4 and/or P-gp will cause an increase in erythromycin bioavailability.

Erythromycin is already known as an inhibitor of OATP $^{3}$, but it is not yet known whether it is a substrate of OATP. Erythromycin is an organic cation. Efflux transporter for organic cations are organic-cation transporters (OCTs), but OCTs have specific substrates, i.e. small organic cations such as choline, tetraethylammonium (TEA), tyramine and tryptamine. ${ }^{15}$ OATP has been known as a multivalent amphiphilic substrate transporter. It transports not only organic anions (bile acids, conjugates, statins, fexofenadine), but also steroids (corticosteroids, cardiac glycosides) and large cations (ajmalinum), etc. ${ }^{3,15}$ Therefore it is probable that erythromycin is also a substrate of OATP.

In the present study, the effect of Siam orange juice on the bioavailability of erythromycin was studied in 13 subjects. The results showed that in total, Siam orange juice decreased the bioavailability of erythromycin, as shown from the decrease in $\mathrm{AUC}_{0-9 h r}$ (Table 1), but the decrease did not reach statistical significance $(\mathrm{p}=$ 0.065). Among 13 subjects, the bioavailability of erythromycin was decreased in 6 subjects (Figure 2), and the decreases were substantial, ranging from approximately 50 to $90 \%$ (Table 2). Since orange juice has been known to inhibit OATP,${ }^{1}$ then it was probable that in these 6 subjects, the OATP was the dominant system and therefore its inhibition produced substantial decreases in erythromycin bioavailability. The dominance of OATP in these subjects were predicted from the high bioavailability of erythromycin when taken with water in 5 of these 6 subjects. This was consistent with Dresser's finding that the magnitude of decrease in fexofenadine AUC was variable among subjects and dependent on the baseline fexofenadine AUC (subjects with the highest fexofenadine AUC with water had the greatest decrease with the juice). ${ }^{1}$ This result also showed indirectly that erythromycin was a substrate of OATP.

In the present study, the bioavailability of erythromycin was found increased in 3 subjects (Figure 2). In these 3 subjects the bioavailability of erythromycin with water were low, indicating that in these subjects, the dominant system was not OATP but P-gp and/or CYP3A4. As already mentioned, Siam orange juice does not contain compounds which inhibit intestinal CYP3A $4{ }^{13}$. Dresser et al. ${ }^{14}$ found that citrus juices (grapefruit juice and orange juice) were not only potent inhibitors of intestinal OATP but also modest inhibitors of intestinal P-gp $(12 \pm 7 \%)$. Since erythromycin is also a substrate of $\mathrm{P}$-gp, it is possible that in subjects with P-gp as the dominant system, orange juice may inhibit intestinal P-gp, resulting in increased bioavailability of erythromycin.

In 4 subjects, the bioavailability of erythromycin was considered unchanged (Figure 2). In fact they consisted of 2 subjects with slightly decreased bioavailability 
and 2 other subjects with slightly increased bioavailability (Table 2). Consistent with the other subjects, the slightly decreased AUC occurred in subjects having high AUC with water, while the slightly increased AUC occurred in subjects having low AUC with water.

Interindividual variability in drug disposition has been shown to result from single-nucleotide polymorphisms (SNPs), not only in CYP enzymes, but also in P-gp ${ }^{16}$ and OATP. ${ }^{17}$ SNPs in protein transporters are associated with reduction in transport activity, and everybody has different balance between the efflux and uptake transporters for absorption.

In the second study with clarithromycin, we expected that the effect of Siam orange juice on clarithromycin bioavailability would be similar to that on erythromycin bioavailability. This is because clarithromycin, similar to erythromycin, is a substrate of both CYP3A4 ${ }^{4}$ and P-gp. ${ }^{7}$ Therefore, similar to erythromycin, the bioavailability of clarithromycin is determined by its absorption across intestinal epithelial cells by passive diffusion, and its metabolism by CYP3A4 in the enterocytes and hepatocytes, ${ }^{4}$ and its efflux by P-gp from the enterocytes back to the intestinal lumen. Clarithromycin is not known whether it is a substrate or an inhibitor of OATP.

In the clarithromycin study, Siam orange juice was shown to slightly decrease the bioavailability $\left(\mathrm{AUC}_{0-12 \mathrm{hr}}\right)$ of clarithromycin, but the decrease was not statistically significant (Table 3). Orange juice decreased clarithromycin bioavailability in 5 subjects, all of them had high AUC with water, in 4 subjects the decreases were more than $20 \%$ while in 1 subject the decrease was only $19 \%$ and therefore was categorized as unchanged bioavailability (Table 4). In these subjects, the high bioavailability with water indicated OATP dominance in their enterocytes, and inhibition of the intestinal OATP by orange juice produced decreases in clarithromycin bioavailability. This result appears to show that clarithromycin is also a substrate of OATP.

Among 12 subjects in the clarithromycin study, orange juice increased clarithromycin bioavailability in 5 subjects, 2 of them had low AUC with water, 3 of them had high AUC with water (Table 4). In 2 subjects having low AUC with water, one subject had only $23 \%$ increase in bioavailability and therefore was categorized as unchanged bioavailability. The low bioavailability with water indicated P-gp dominance in their enterocytes. Since clarithromycin is also a substrate of P-gp, then inhibition of the intestinal P-gp by orange juice produced increases in clarithromycin bioavailabity. How about the 3 subjects who had high AUC with water (one subject had only $15.5 \%$ increase in bioavailability and therefore was categorized as unchanged bioavailability), they should have OATP dominance in their enterocytes, and inhibition of the intestinal OATP by orange juice should produce decreases in clarithromycin bioavailability, and yet the fact was orange juice increased the bioavailability of clarithromycin in these subjects. As already mentioned above, Siam orange juice does not inhibit intestinal CYP3A4, but inhibits intestinal OATP potently and intestinal P-gp modestly. Therefore the only explanation for increased clarithromycin bioavailability due to Siam orange juice in these 3 subjects having high AUC with water was inhibition of intestinal P-gp.

Five subjects in the clarithromycin study were categorized to have unchanged bioavailability. Among them, 1 subject actually had decreased bioavailability (19\% decrease), and 2 subjects had increased bioavailability (15.5\% and $23 \%$ increased) (Table 4). The remaining 2 subjects had essentially unchanged bioavailability, and they had high AUC with water. In these last 2 subjects, unchanged bioavailability seemed to indicate that high activities of both OATP and P-gp were absent, while the high bioavailability seemed to result from inhibition of CYP3A4 by clarithromycin itself which was unaffected by orange juice.

It was concluded that coadministration of Siam orange juice with erythromycin or clarithromycin produced unpredictable effects on the bioavailability of these antibacterials in individual subjects, with marked decreases in almost half of the subjects, although in totals the effects were not statistically significant.

\section{REFERENCES}

1. Dresser GK, Baily DG, Leake BF, Schwarz UI, Dawson PA, Freeman DJ, et al. Fruit juices inhibit organic anion transporting polypeptide-mediated drug uptake to decrease the oral bioavailability of fexofenadine. Clin Pharmacol Ther 2002; 71: 11-20.

2. Cvetkovic M, Leake B, Fromm MF, Wilkinson GR, Kim RB. OATP and P-glycoprotein transporters mediate the cellular uptake and excretion of fexofenadine. Drug Metab Dispos 1999; 27(8) : 866-71.

3. Hansten PD, Levy RH. Role of P-glycoprotein and organic anion transporting polypeptides in drug absorption and distribution. Clin Drug Invest 2001; 21(8) : 587-96. 
4. Michalets EL. Update : clinically significant cytochrome P-450 drug interactions. Pharmacotherapy 1998; 18(1) : 84-112.

5. Human intestinal transport system : substrates, activators, and inhibitors. Available from : http://bigfoot.med.enc.edu/watkinsLab/intesinfo.htm

6. Rodriguez I, Abernethy DR, Woosley RL. P-glycoprotein in clinical cardiology [Editorial]. Circulation 1999; 99: 472-4.

7. Drug transporters : impact on commonly prescribed antihistamines and other drugs. Available from : http://www.cinelearninglab.com/slide-list.html

8. Goodman \& Gilman's the pharmacological basis of therapeutics. 10th ed. New York : McGraw-Hill; 2001. p. 1943.

9. Wacher VJ, Wu C-Y, Benet LZ. Overlapping substrate specificity and tissue distribution of cytochrome P4503A and P-glycoprotein. Molec Carcinogenesis 1995; 13: 129-34.

10. Kim RB, Wandel C, Leake B, Cvetkovic M, Fromm MF, Dempsey PJ, et al. Interrelationship between substrates and inhibitors of human CYP3A and P-glycoprotein. Pharm Res 1999; 16(3) : 408-14.
11. Setiawan AI, Trisnawati Y. Peluang usaha dan pembudidayaan jeruk Siam. Jakarta : Penebar Swadaya; 2002. p. 1-10.

12. Pracaya. Jeruk manis : varietas, budidaya dan pascapanen. Jakarta : Penebar Swadaya; 2002. p. 1-29, 143-6.

13. Survey of phenolic compounds produced in citrus : flavonoid composition of citrus. Available from : http://www.ars.usda.gov/is/np/phenolics/comp.htm

14. Dresser GK, Schwarz UI, Leake B, Choo EF, Wilkinson GR, Bailey DG. Citrus juices are potent inhibitors of intestinal OATP but not P-glycoprotein (PI-89). Clin Pharmacol Ther 2001; 69(2) : 23.

15. Koepsell H. Organic cation transporters in intestine, kidney, liver, and brain. Annu Rev Physiol 1998; 60: 243-66.

16. Kim RB, Leake BF, Choo EF, Dresser GK, Kubba SV, Schwarz UI, et al. Identification of functionally variant MDR1 alleles among European Americans and African Americans. Clin Pharmacol Ther 2001; 70: 189-99.

17. Tirona RG, Leake BF, Merino G, Kim RB. Polymorphisms of OATP-C. J Biol Chem 2001; 276 (38) : 35669-75. 